\title{
Understanding food web mercury accumulation through trophic transfer and carbon processing along a river affected by recent run-of-river dams
}

Dominic E. Ponton ${ }^{1}$, Raphaël A. Lavoie ${ }^{1,4}$, Maxime Leclerc ${ }^{1}$, François Bilodeau², Dolors

Planas $^{3}$, Marc Amyot ${ }^{*}$

${ }^{1}$ GRIL, Département des sciences biologiques, Université de Montréal, Montréal, Québec, Canada, H2V 0B3.

${ }^{2}$ Hydro-Québec, Direction Environnement, 800 boul. De Maisonneuve Est, Montréal, Québec, H2Z 1 A4.

${ }^{3}$ GRIL, Département des sciences biologiques, Université du Québec à Montréal, Montréal, Québec, Canada, H2X 3 Y7.

${ }^{4}$ Canadian Wildlife Service, Environment and Climate Change Canada, 801-1550 avenue d’Estimauville, Québec, Québec, Canada, G1J 0C3.

This document includes 6 text sections, 4 tables, and 8 figures.

*Corresponding author: m.amyot@umontreal.ca 


\section{Table of contents}

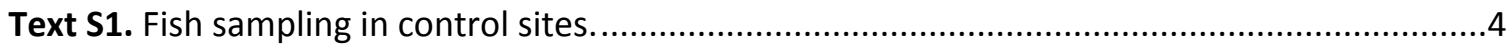

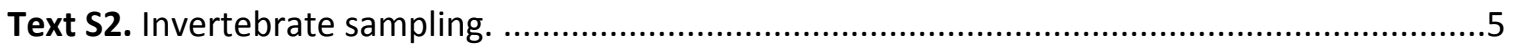

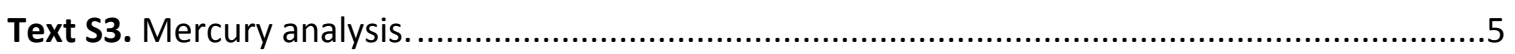

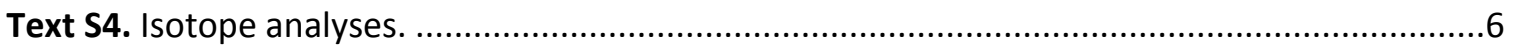

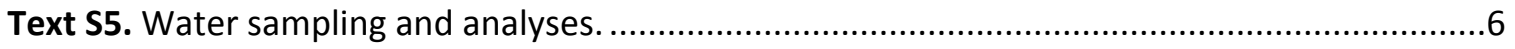

Text S6. Yellow perch population change and size distribution................................................

Table S1. Mercury concentrations (length-standardized ([ $\left.\mathrm{THg}_{\text {std }}\right]$ ), average, minimum, maximum) and total fish length (average, minimum, maximum) from northern pike and walleye collected from the control lakes and the Saint-Maurice River sectors. Significant differences in $\left[\mathrm{THg}_{\text {std }}\right]$ are presented with different letters in the "Test" column. Further details are provided in Text S1. BALT: between the Beaumont and La Tuque power plants; LTGM: between the La Tuque and Grand-Mère power plants. See Figure 1 for other acronyms and more information is presented in Text S1.

Table S2. MeHg concentrations of primary consumers (log[MeHg]; $\mathrm{gg} / \mathrm{g} \mathrm{dw}$ ) and nitrogen stable isotopes signature $\left(\delta^{15} \mathrm{~N} ; \%\right.$ ) from the sectors used for baseline adjustment of the complete trophic chain. Standard deviation (SD), standard error (SE), and sample number $(n)$ are presented.

Table S3. Results of the linear mixed models for each organismal groups. Best models for each group are indicated in bold underline (AIC $>4$ ).

Table S4. Trophic magnification slopes (TMS, log ng/g.\%o), trophic magnification intercepts (TMI), standard error (SE), TMS coefficient of determination (TMS, $r^{2}$ ), $p$-value, and the degree of freedom (DF) of each regression for all organisms (top) and high trophic level fish (bottom)....12

Figure S1: Relative abundance of yellow perch (Perca flavescens) in the run-of-river pondages of Chute-Allard (CAUP) and Rapides-des-Coeurs (RDC) recorded during four community surveys between 2002 and 2016. The impoundment is indicated by the vertical short-dashed line, and the occurrence of a wildfire in proximity to CAUP is indicated by the vertical long-dashed line..13

Figure S2. Box and whisker plots presenting log-transformed MeHg concentrations (log[MeHg], $\mathrm{ng} / \mathrm{g} \mathrm{dw}$ ) in minnows (juvenile Semotilus corporalis) from various sectors. Flooded sectors are presented in red.

Figure S3. Log-transformed methylmercury concentrations in fish muscle (log [MeHg] (ng/g dw)) as a function of their baseline-adjusted nitrogen stable isotopic signature $\left(\delta^{15} \mathrm{~N}_{\text {adjj }} \%\right.$ o) for all fish sampled from the Saint-Maurice River sectors from immediately downstream of the Gouin Reservoir (REF1) to the Blanc Reservoir (RB; see Figure 1).

Figure S4. Regression between $\log [\mathrm{MeHg}](\mathrm{ng} / \mathrm{g} \mathrm{dw})$ and the adjusted nitrogen stable isotopic signature $\left(\delta^{15} \mathrm{~N}_{\mathrm{adj}} ; \%\right.$ \%) for (a) fish at a trophic level lower than 3.5 and (b) invertebrates collected 
from sectors along the Saint-Maurice River. Slopes are $-0.06 \pm 0.03$ and $0.15 \pm 0.02$ for panels a and $b$, respectively.

Figure S5: Fish carbon isotopic signatures $\left(\delta^{13} \mathrm{C} ; \%\right.$ ) from the sectors of the Saint-Maurice River for (a) all sampled fish, (b) walleye (Sander vitreus), and (c) northern pike (Esox Lucius). We observed no significant differences for yellow perch (Perca flavescens; not presented). Red boxplots represent flooded sites. Different letters represent significant differences.

Figure S6. Log-transformed methylmercury concentrations (Log [MeHg], ng/g dw) as a function of the sector-specific adjusted nitrogen stable isotopic signature $\left(\delta^{15} \mathrm{~N}_{\mathrm{adj}}, \%\right.$ ) for (a) all sampled organisms and (b) high trophic level fish collected from the Saint-Maurice River, Quebec. Degrees of freedom are presented with the TMS. Significant differences in trophic magnification slopes (TMS; log ng/g.\%o) and trophic magnification intercepts (TMl; log [MeHg], ng/g dw) are presented in Figure S6. The coefficients of determination $\left(r^{2}\right)$ and $p$-values are presented in Table S3 and Figure S6 (for all TMS, $r^{2}>0.43$ and $p<0.008$ ).

Figure S7: Bar graphs of (a) trophic magnification slopes (TMS; $\mathrm{ng} /(\mathrm{g} \mathrm{dw} \% \%)$ ) and (b) trophic magnification intercepts (TMl; log[MeHg], ng/g dw). Regressions (c-h) between log-transformed methylmercury concentrations ( $\log [\mathrm{MeHg}], \mathrm{ng} / \mathrm{g} \mathrm{dw}$ ) and their baseline-adjusted nitrogen stable isotopic signature $\left(\delta^{15} \mathrm{~N}_{\mathrm{adj}}, \%\right.$ ) for all organisms sampled along the Saint-Maurice River. Graphs are organized ( $c$ through $h$ ) from upstream to downstream from the junction of the Najoua and Saint-Maurice rivers (NSM) to the Blanc Reservoir (BR). Open black circles are samples from all sectors, and other symbols are for specific panel sectors. Different letters present significant differences between sectors.

Figure S8: Log-transformed methylmercury concentrations of primary consumers (log $[\mathrm{MeHg}]$, $\mathrm{ng} / \mathrm{g} \mathrm{dw}, \pm \mathrm{SE}$, details in Table S1) as a function of (a) trophic magnification intercepts ( $\log [\mathrm{MeHg}], \mathrm{ng} / \mathrm{g}$ dw, $\pm \mathrm{SE}$, details in Table S2); (b) dissolved [MeHg] ([MeHg] water, $0.45 \mu \mathrm{m}, \pm \mathrm{SE}, n=$ 3-48); (c) total dissolved nitrogen ( $\mathrm{TN}_{\text {water, } 0.45 \mu \mathrm{m}}, \mu \mathrm{g} / \mathrm{L}, \pm \mathrm{SE}, n=3-48$ ); and (d) aqueous total phosphorus ( $\mathrm{TP}_{\text {water }} ; \mu \mathrm{g} / \mathrm{L}, \pm \mathrm{SE}, n=3-48$ ). Dashed regressions (b) and (d) are not significant ( $p>$ $0.05)$ 
Text S1. Fish sampling in control sites.

We did not collect fish in all sectors prior to impoundment; consequently, our temporal comparison relies on fish collected in 1990-1992 from several control sites along the Saint-Maurice River and from regional lakes (Table S1). The sampled sites were lakes Bréhard $\left(47^{\circ} 52.158^{\prime} \mathrm{N} ; 73^{\circ} 48.734^{\prime} \mathrm{W}\right)$, Cécile $\left(48^{\circ} 34.979^{\prime} \mathrm{N} ; 7^{\circ} 44.834^{\prime} \mathrm{W}\right)$, Rinfret $\left(48^{\circ} 24.512^{\prime} \mathrm{N} ; 73^{\circ} 39.670^{\prime} \mathrm{W}\right)$, and Faguy $\left(48^{\circ} 32.432^{\prime} \mathrm{N} ; 74^{\circ} 5.034^{\prime} \mathrm{W}\right)$, and the Gouin Reservoir $\left(48^{\circ} 23.021^{\prime} \mathrm{N} ; 74^{\circ} 10.230^{\prime} \mathrm{W}\right)$. The latter was flooded at the beginning of the $20^{\text {th }}$ century (1916-1917), and fish $[\mathrm{Hg}]$ is now back to its natural range. ${ }^{1}$ Sampled sectors along the Saint-Maurice River for 1990-1992 were situated between the Beaumont and La Tuque power plants (BALT, 47 $29.014^{\prime} \mathrm{N} ; 7^{\circ} 47.205^{\prime} \mathrm{W}$ ), close to the Rapide-desCoeurs (RDC; Figure 1), and the Chaudière Rapids (CR; Figure 1). ${ }^{2}$ Fish collected in 2013 from the reference zone (REF1; Figure 1), downstream of the Gouin Reservoir, were included in the natural $[\mathrm{Hg}]$ range $(\mathrm{CTL})$. Walleye $(n=259)$ were collected from the abovementioned sectors, although not from Cécile and Rinfret lakes, as well as from Lake Bob-Grant $\left(47^{\circ} 44.483^{\prime} \mathrm{N} ; 73^{\circ} 31.349^{\prime} \mathrm{W}\right)$, from sites between the La Tuque and GrandMère power plants (LTGM, $\left.46^{\circ} 46.172^{\prime} \mathrm{N} ; 72^{\circ} 47.596^{\prime} \mathrm{W}\right)$, and from the Blanc Reservoir (Figure 1) during the same period (1990-1992). We collected yellow perch $(n=38)$ from sites between the La Tuque and Grand-Mère power plants (LTGM) to determine the regional standardized $\mathrm{Hg}$ concentration range. ${ }^{3}$

Ethics. We placed the minnows in cool, aerated river water for their transport to the laboratory. In the laboratory, these fish were sacrificed by decapitation after measuring their weight and length (ethic protocol approved by the Comité de déontologie de l'expérimentation sur les animaux (CDEA-19-038)). 
Text S2. Invertebrate sampling.

We sorted invertebrates by size immediately after capture to avoid inter-invertebrate predation. In the laboratory, we identified collected individuals to the family level. Families were: Aeshnidae, Asellidae, Beatiscidae, Calopterygidae, Coenagrionidae, Corixidae, Dytiscidae, Gammaridae, Gerridae, Gomphidae, Gyrinidae, Haliplidae, Hydrobiidae, Hydrophilidae, Libellulidae, Limnephilidae, Lymnaeidae, Nepidae, Notonectidae, Phryganeidae, Physidae, Planorbidae, and Sphaeriidae. When biomass was not high enough ( $<3 \mathrm{mg} \mathrm{dw}$ ), similar-sized individuals were pooled prior to analyses. Samples were frozen at $-20{ }^{\circ} \mathrm{C}$ in acid-washed $(10 \% \mathrm{HCl}) 5 \mathrm{~mL}$ glass vials. Mollusks were dissected for analysis of their soft tissues. We collected zooplankton using a zooplankton net or a kick-net when they were attached to macrophytes. We sorted the zooplankton in the laboratory by flotation/decantation, and then filtered the samples through various mesh sizes to remove debris and colonial algae. Samples were composed of $>90 \%$ zooplankton by volume.

Text S3. Mercury analysis.

Veritas Laboratories proceeded by digesting approx. $0.5 \mathrm{~g}$ of wet tissue overnight in sulfuric and nitric acids at room temperature. They then added potassium peroxydisulfate and permanganate and further digested the tissues at $95{ }^{\circ} \mathrm{C}$ for $2 \mathrm{~h}$. For each sample, a mix of sodium chloride and hydroxylamine chloride was added to the digested samples, and the sample was then diluted to a total volume of $50 \mathrm{~mL}$ prior to analysis.

For small organisms (minnows and invertebrates), we slightly modified our analytical protocol to measure $\mathrm{MeHg}$, total $\mathrm{Hg}$, and metals from the same tissue digestate when the available biomass was limited. This process has been previously tested and used in our laboratory. ${ }^{4}$ We placed 1-4 mg of dry tissue into $6 \mathrm{~mL}$ polytetrafluoroethylene vials. We then added $1 \mathrm{~mL}$ of diluted $\mathrm{HNO}_{3}\left(3 \mathrm{M} ; \mathrm{HNO}_{3}\right.$ OmniTrace UltraTM, MilliporeSigma) to digest the sample overnight at $65^{\circ} \mathrm{C}$. A $50 \mu \mathrm{L}$ aliquot was used for MeHg analysis, as described above. We then added $330 \mu \mathrm{L}$ of concentrated $\mathrm{HNO}_{3}$ and $150 \mu \mathrm{L}$ of 
concentrated $\mathrm{HCl}$ to the remainder of the digested samples. The samples were submitted to a second digestion in an industrial pressure cooker (All American) for $3 \mathrm{~h}$ at $121^{\circ} \mathrm{C}$ at a pressure of $1.4 \mathrm{~kg} / \mathrm{cm}^{2}$ (20 psi), and $250 \mu \mathrm{L} \mathrm{H} \mathrm{O}_{2}$ was added for digestion overnight at room temperature. Samples were diluted to $15 \mathrm{~mL}$ (final dilution: $\mathrm{HNO}_{3} 4 \%$ and $\mathrm{HCl} 1 \%$ ), and we used $1 \mathrm{~mL}$ for total $\mathrm{Hg}$ analysis by CVAFS (Tekran 2600, Tekran Instruments Corporation), following U.S. EPA method 1631 (detection limit of $0.04 \mathrm{ng} / \mathrm{L}, 0.1 \mathrm{ng} / \mathrm{g}$ ). Inorganic $\mathrm{Hg}$ analyses met the criteria of the Canadian Association for Laboratory Accreditation intercalibration. TORT-2 [MeHg] (149 $\pm 19 \mathrm{ng} / \mathrm{g} ; \pm \mathrm{SD}, n=33)$ were within the accepted certified range (152 $\pm 13 \mathrm{ng} / \mathrm{g}$ ( \pm confidence interval $(\mathrm{Cl})$ ).

Text S4. Isotope analyses.

For nitrogen and carbon isotopes, two internal reference materials $\left(\delta^{15} \mathrm{~N}=-0.10 \% \pm\right.$ $0.24 \%$ and $+14.95 \%$ o $\pm 0.09 \%$; $\delta^{13} \mathrm{C}=-28.73 \%$ $\pm 0.06 \%$ ond $-11.85 \%$ o $\pm 0.04 \%$ ) were used to normalize the results on the AIR (IAEA-N1, IAEA-N2 \& IAEA-N3) and NBS19-LSVEC scale for nitrogen and carbon, respectively. A third reference material $\left(\delta^{15} \mathrm{~N}=-0.1 \% \circ \pm\right.$ $0.15 \%$; $\delta^{13} \mathrm{C}=-17.04 \% \pm 0.11 \%$ ) was analyzed as an unknown sample to assess the precision of the normalization. Results are given in delta units $(\delta)$ in per mill (\%o) vs AIR and Vienna Pee Dee Belemnite (VPDB) for nitrogen and carbon isotopes, respectively. The overall analytical uncertainty $(1 \mathrm{~s})$ is better than $\pm 0.2 \%$ ond $\pm 0.1 \%$ o for nitrogen and carbon, respectively. This uncertainty is based on the propagation of uncertainties of the normalization of the internal reference materials and the samples, but it does not include the homogeneity or the representativeness of the sample.

Text S5. Water sampling and analyses.

All labware was soaked in a solution of $45 \%$ nitric acid $\left(\mathrm{HNO}_{3}\right)$ and $10 \%$ hydrochloric acid $(\mathrm{HCl}$; volume/volume $(\mathrm{v} / \mathrm{v}))$ and rinsed five times with ultrapure water (18 Mohm·cm). Prior to sample collection, tubing was washed with hydrochloric acid $(10 \%(v / v))$, then rinsed with Milli-Q water and site water for two minutes each. A blank was run with this capsule after five sites and then discarded. Blank average value for total $\mathrm{Hg}(0.05 \pm 0.05$ 
$( \pm S D) n g / L)$ and MeHg $(0.01 \pm 0.01( \pm S D) n g / L)$ represented $4.0 \%$ and $7.3 \%$ of the average value for all sites, respectively.

Preserved water samples $\left(0.04 \% \mathrm{HCl}(\mathrm{v} / \mathrm{v})\right.$, kept at $\left.4{ }^{\circ} \mathrm{C}\right)$ were analyzed for total $\mathrm{Hg}$ following the U.S. EPA 1631 protocol with a Tekran 2600 cold vapor atomic fluorescence spectrometer (CVAFS). ${ }^{5}$ Briefly, bromine monochloride $(\mathrm{BrCl})$ was added to samples for oxidation and tin chloride $\left(\mathrm{SnCl}_{2}\right)$ for reduction before volatile $\mathrm{Hg}(0)$ collection onto a gold trap following argon-purging. The total $\mathrm{Hg}$ concentration was then detected into the CVAFS after a second gold trap amalgamation. The detection limit was $0.04 \mathrm{ng} / \mathrm{L}$ based on the analysis of ten Milli-Q blanks. Analyses for aqueous [MeHg] were based on the 1630 EPA protocol using a Tekran 2700 CVAFS for distilled samples to remove organic matter and sulfide residues. ${ }^{6}$ Sodium tetraethylborate $\left(\mathrm{NaB}(\mathrm{Et})_{4}\right)$ was added to help form two volatile $\mathrm{Hg}$ species (methyl-ethyl $\mathrm{Hg}$ and diethylHg). As a control, we used Milli-Q water spiked with the digested lobster hepatopancreas reference material TORT-2 (National Research Council of Canada) before the distillation process. The water sample was argon-purged to liberate the volatile species, which were then separated through a gas chromatograph (GC) in the Tekran instrument. MeHg was ultimately detected in the cell of the CVAFS.

Dissolved gases $\left(\mathrm{CO}_{2}\right.$ and $\left.\mathrm{CH}_{4}\right)$ were extracted from triplicate $100 \mathrm{~mL}$ water samples into $40 \mathrm{~mL}$ headspaces via exchange across the liquid-gas interface after $2 \mathrm{~min}$ of vigorous shaking. The initial headspace was composed of hydrocarbon-free Ultra-zero air (Praxair), and final headspaces were transferred to pre-evacuated $12 \mathrm{~mL}$ vials (Exetainer, Labco) for transport to the lab. To determine the concentration and $\delta^{13} \mathrm{C}$ isotopic signatures of $\mathrm{CO}_{2}$ and $\mathrm{CH}_{4}$, we ran headspace samples on a cavity ringdown spectrometer (CRDS, Picarro 2201-i), with the aid of an auto-sampler (SAM, OpenAutoSampler). The original concentration and $\delta^{13} \mathrm{C}$ isotopic signatures of $\mathrm{CO}_{2}$ and $\mathrm{CH}_{4}$ in the water were then calculated as a function of these headspace values, headspace ratios, temperature, pressure, and the isotopic fractionation across the liquid-gas interface. ${ }^{7}$ 
Total and dissolved (filtration on $0.45 \mu \mathrm{m}$ ) phosphorus were analyzed by the reaction of orthophosphates with molybdenum (VI) and antimony (III) in an acid medium to form a phosphoantimonylmolybdenum complex. This complex was subsequently reduced by ascorbic acid to a heteropolyblue with an absorbance maximum at $660 \mathrm{~nm}$ or $880 \mathrm{~nm}$. This method has been documented by EPA method 365.3. ${ }^{8}$ Total and dissolved (filtration on $0.45 \mu \mathrm{m}$ ) nitrogen were measured by digesting water samples with persulfate at 120 ${ }^{\circ} \mathrm{C}$ for $45 \mathrm{~min}$ to transform all species to nitrate. Nitrate is quantitatively reduced to nitrite by the passage of the sample through a copperized cadmium column. The nitrite is then determined by diazotizing with sulfanilamide followed by coupling with $\mathrm{N}-(1-$ naphthyl)ethylenediamine dihydrochloride. The resulting water-soluble dye has a magenta color, which is read at $520 \mathrm{~nm} .{ }^{9}$ Dissolved organic carbon (DOC) in surface waters was measured as non-purgeable organic carbon by adding $\mathrm{H}_{3} \mathrm{PO}_{4}$, followed by persulfate digestion, using an Aurora 1030 TOC analyzer (OI Analytical, Texas).

Text S6. Yellow perch population change and size distribution.

We verified whether northern pike were smaller in CC compared with other sectors, which could explain the low calculated $\left[\mathrm{THg}_{\text {std }}\right]$. We compared small northern pike [THg] in CC with those from CAUP and/or RDC sectors, and this analysis resulted to the same conclusion as with all fish; the [THg] in small northern pike was lower in CC than in other sectors. Yellow perch distribution size was comparable among sectors; therefore, this species size variability among sectors could not explain the lower $\left[\mathrm{THg}_{\text {std }}\right]$ in $\mathrm{CC}$.

Changes in the abundance of a specific taxon of the food web could have led to a change in the efficiency of $\mathrm{Hg}$ transfer through the food chain, thereby leading to top predators like walleye and northern pike. If such a change occurred, it could have an influence on the TMS. Fish community abundance and diversity surveys in 2013 and 2016 revealed an increased abundance of yellow perch ${ }^{10}$. The relative abundance of Perca flavescens rose from about $10 \%$ before the hydroelectric power plant construction to more than $35 \%$ after impoundments of the RDC and CAUP reservoirs ( $\mathrm{SI}$, Section 4, Figure S3). This rise is 
in part a consequence of an increase in yellow perch catch per unit of effort (CPUE) from 2002 to 2016 (from 0.6 to 2.6 individuals/night-net) and a decrease in CPUE of other species, such as longnose sucker (1.1 to 0.4 individuals/night-net), white sucker (1.6 to 0.7 individuals/night-net), and fallfish (0.6 to 0.3 individuals/night-net ).

As a proxy for cannibalism, we tested whether $\delta^{15} \mathrm{~N}$ values were more variable (higher standard deviation) in sectors where yellow perch abundance increased (CAUP and RDC). The logic is that large yellow perch feeding on smaller perch should have a higher $\delta^{15} \mathrm{~N}$ than large yellow perch feeding on invertebrates; thus, this scenario would lead to a higher variation of $\delta^{15} \mathrm{~N}$ in cannibal subpopulations. We did not observe any significant relationship between yellow perch $\delta^{15} \mathrm{~N}$ standard deviations and their [THg].

From the analysis of yellow perch stomach contents, we found no evidence that cannibalism was higher in sites where yellow perch abundance was higher. The occurrence of fish in yellow perch stomachs was low. No fish were observed in the 32 yellow perch collected from CAUP in 2016. The occurrence of fish in yellow perch stomachs was highest in sectors RDC ( $15 \%$ of sampled yellow perch) and RB ( $21 \%$ of sampled yellow perch). Among all sites, invertebrates were found at the highest abundance in yellow perch stomach contents from CAUP $(67 \%)$ and RDC $(40 \%)$, suggesting that invertebrates were an important source of food for yellow perch in the sites where flooding had occurred. These results suggest that the increased abundance of yellow perch did not lead to more cannibalism and a higher predator-mercury exposure. 
Table S1. Mercury concentrations (length-standardized $\left(\left[\mathrm{THg}_{\text {std }}\right]\right)$, average, minimum, maximum) and total fish length (average, minimum, maximum) from northern pike and walleye collected from the control lakes and the Saint-Maurice River sectors. Significant differences in $\left[\mathrm{THg}_{\text {std }}\right]$ are presented with different letters in the "Test" column. Further details are provided in Text S1. BALT: between the Beaumont and La Tuque power plants; LTGM: between the La Tuque and Grand-Mère power plants. See Figure 1 for other acronyms and more information is presented in Text S1.

\begin{tabular}{|c|c|c|c|c|c|c|c|c|c|c|}
\hline \multirow{2}{*}{ Species } & \multirow{2}{*}{ Waterbody } & \multirow{2}{*}{$n$} & \multicolumn{5}{|c|}{ [THg] $(\mu \mathrm{g} / \mathrm{g}$ ww) } & \multicolumn{3}{|c|}{ Length (mm) } \\
\hline & & & {$\left[\mathrm{THg}_{\mathrm{std}}\right]$} & Test & Average & Minimum & Maximum & Average & Minimum & Maximum \\
\hline \multirow{9}{*}{$\begin{array}{l}\text { Northern } \\
\text { Pike }\end{array}$} & Lake Bréhard & 43 & 0.64 & $b c$ & 0.57 & 0.21 & 1.50 & 571 & 485 & 715 \\
\hline & Lake Cécile & 23 & 0.74 & $a b$ & 0.74 & 0.16 & 1.36 & 570 & 198 & 820 \\
\hline & Lake Faguy & 22 & 0.74 & $a b$ & 1.03 & 0.21 & 2.78 & 715 & 324 & 1080 \\
\hline & Lake Rinfret & 25 & 0.74 & a & 0.75 & 0.47 & 1.07 & 631 & 396 & 952 \\
\hline & Gouin Reservoir & 16 & 0.74 & $a b$ & 0.87 & 0.34 & 2.37 & 621 & 392 & 1020 \\
\hline & BALT & 19 & 0.74 & $a b$ & 0.79 & 0.50 & 1.80 & 585 & 493 & 931 \\
\hline & $\mathrm{RDC}$ & 21 & 0.64 & $a b c$ & 0.55 & 0.16 & 1.47 & 524 & 315 & 908 \\
\hline & CR & 20 & 0.74 & $a b$ & 0.70 & 0.36 & 1.47 & 615 & 430 & 890 \\
\hline & REF1 & 30 & 0.55 & c & 0.51 & 0.15 & 1.32 & 553 & 323 & 789 \\
\hline \multirow{10}{*}{ Walleye } & Lake Bob-Grant & 21 & 0.59 & bc & 0.60 & 0.18 & 2.11 & 366 & 190 & 670 \\
\hline & Lake Bréhard & 14 & 0.30 & $d$ & 0.38 & 0.17 & 0.62 & 401 & 212 & 495 \\
\hline & Lake Faguy & 28 & 0.72 & $a b$ & 0.80 & 0.33 & 2.39 & 384 & 173 & 764 \\
\hline & Gouin Reservoir & 29 & 0.50 & c & 0.48 & 0.23 & 0.94 & 373 & 197 & 553 \\
\hline & BALT & 26 & 0.84 & a & 1.21 & 0.53 & 3.50 & 439 & 324 & 601 \\
\hline & LTGM & 36 & 0.54 & c & 0.87 & 0.11 & 2.35 & 438 & 119 & 671 \\
\hline & Blanc Reservoir & 30 & 0.84 & a & 1.04 & 0.44 & 2.64 & 431 & 312 & 595 \\
\hline & $\mathrm{RDC}$ & 48 & 0.84 & a & 1.13 & 0.14 & 3.40 & 405 & 120 & 650 \\
\hline & CR & 27 & 0.84 & a & 0.98 & 0.33 & 2.23 & 429 & 265 & 530 \\
\hline & REF1 & 30 & 0.49 & c & 0.47 & 0.13 & 0.89 & 354 & 133 & 571 \\
\hline
\end{tabular}


Table S2. MeHg concentrations of primary consumers (log[MeHg]; ng/g dw) and nitrogen stable isotopes signature $\left(\delta^{15} \mathrm{~N} ; \%\right.$ ) from the sectors used for baseline adjustment of the complete trophic chain. Standard deviation (SD), standard error (SE), and sample number $(n)$ are presented.

\begin{tabular}{llllllllll}
\hline Sectors & $\begin{array}{l}\log [\mathbf{M e H g}] \\
(\mathbf{n g} / \mathbf{g} \mathbf{d w})\end{array}$ & SD & $\boldsymbol{n}$ & SE & $\begin{array}{l}\text { Tukey } \\
\text { test }\end{array}$ & $\begin{array}{l}\boldsymbol{\delta}^{15} \mathbf{N} \\
(\%)\end{array}$ & SD & $\boldsymbol{n}$ & SE \\
\hline \hline CAUP & 2.07 & 0.30 & 71 & 0.04 & a & 3.3 & 1.2 & 74 & 0.14 \\
RDC & 1.75 & 0.33 & 33 & 0.05 & bd & 3.4 & 1.5 & 34 & 0.26 \\
CC & 1.99 & 0.30 & 53 & 0.04 & ac & 2.4 & 0.8 & 53 & 0.11 \\
NSM & 1.30 & 0.30 & 3 & 0.17 & b & 3.0 & 0.5 & 3 & 0.29 \\
BR & 1.63 & 0.40 & 17 & 0.10 & b & 2.5 & 0.8 & 19 & 0.18 \\
MR & 1.91 & 0.30 & 30 & 0.05 & ad & 3.2 & 0.8 & 33 & 0.14 \\
REF2 & 1.80 & 0.03 & 15 & 0.01 & bcd & 3.5 & 0.6 & 11 & 0.18 \\
\hline
\end{tabular}

Table S3. Results of the linear mixed models for each organismal groups. Best models for each group are indicated in bold underline (AIC $>4$ ).

\begin{tabular}{|c|c|c|c|c|}
\hline Group & Independent & AIC & Marginal $r^{2}$ & Conditional $r^{2}$ \\
\hline \multirow{3}{*}{ All organisms } & $\delta^{15} \mathrm{~N}_{\mathrm{adj}}$ & 445 & 0.65 & 0.76 \\
\hline & $\delta^{13} \mathrm{C}$ & 1450 & 0.01 & 0.22 \\
\hline & $\delta^{15} \mathrm{~N}_{\mathrm{adj}} * \delta^{13} \mathrm{C}$ & 322 & 0.71 & 0.80 \\
\hline \multirow{3}{*}{$\begin{array}{l}\text { Primary } \\
\text { consumers }\end{array}$} & $\delta^{15} \mathrm{~N}_{\mathrm{adj}}$ & 95 & 0.05 & 0.39 \\
\hline & $\delta^{13} \mathrm{C}$ & $\underline{58}$ & 0.24 & 0.47 \\
\hline & $\delta^{15} \mathrm{~N}_{\mathrm{adj}} * \delta^{13} \mathrm{C}$ & $\underline{59}$ & 0.22 & 0.57 \\
\hline \multirow{3}{*}{$\begin{array}{l}\text { Secondary } \\
\text { consumers }\end{array}$} & $\delta^{15} N_{a d j}$ & 9 & 0.01 & 0.36 \\
\hline & $\delta^{13} \mathrm{C}$ & -10 & 0.25 & 0.42 \\
\hline & $\delta^{15} \mathrm{~N}_{\mathrm{adj}}{ }^{*} \delta^{13} \mathrm{C}$ & -41 & 0.24 & 0.49 \\
\hline \multirow{3}{*}{ All invertebrates } & $\delta^{15} \mathrm{~N}_{\mathrm{adj}}$ & 230 & 0.21 & 0.43 \\
\hline & $\delta^{13} \mathrm{C}$ & 259 & 0.26 & 0.35 \\
\hline & $\delta^{15} \mathrm{~N}_{\mathrm{adj}}{ }^{*} \delta^{13} \mathrm{C}$ & $\underline{137}$ & 0.24 & 0.65 \\
\hline \multirow{3}{*}{$\begin{array}{l}\text { Low trophic level } \\
\text { fish }\end{array}$} & $\delta^{15} \mathrm{~N}_{\mathrm{adj}}$ & 23 & 0.00 & 0.46 \\
\hline & $\delta^{13} \mathrm{C}$ & $\underline{-5}$ & 0.07 & 0.38 \\
\hline & $\delta^{15} \mathrm{~N}_{\mathrm{adj}}{ }^{*} \delta^{13} \mathrm{C}$ & $\underline{-9}$ & 0.09 & 0.46 \\
\hline \multirow{3}{*}{$\begin{array}{l}\text { High trophic } \\
\text { level fish }\end{array}$} & $\delta^{15} \mathrm{~N}_{\mathrm{adj}}$ & -28 & 0.53 & 0.73 \\
\hline & $\delta^{13} \mathrm{C}$ & 126 & 0.00 & 0.30 \\
\hline & $\delta^{15} \mathrm{~N}_{\mathrm{adj}} * \delta^{13} \mathrm{C}$ & $\underline{-21}$ & 0.52 & 0.74 \\
\hline \multirow{3}{*}{ All fish } & $\delta^{15} \mathrm{~N}_{\mathrm{adj}}$ & 181 & 0.41 & 0.63 \\
\hline & $\delta^{13} \mathrm{C}$ & 468 & 0.00 & 0.24 \\
\hline & $\delta^{15} \mathrm{~N}_{\mathrm{adj}} * \delta^{13} \mathrm{C}$ & $\underline{125}$ & 0.43 & 0.65 \\
\hline
\end{tabular}


Table S4. Trophic magnification slopes (TMS, log ng/g.\%o), trophic magnification intercepts (TMI), standard error (SE), TMS coefficient of determination (TMS, $r^{2}$ ), $p$-value, and the degree of freedom (DF) of each regression for all organisms (top) and high trophic level fish (bottom).

\begin{tabular}{lllllllll}
\hline Sector & Sample & TMS & SE & TMI & SE & TMS $\boldsymbol{r}^{2}$ & $\boldsymbol{p}$-value & DF \\
\hline \hline Global & All & 0.194 & 0.005 & 2.04 & 0.02 & 0.66 & $<2.2 \mathrm{E}-16$ & 868 \\
CAUP & All & 0.185 & 0.008 & 2.27 & 0.03 & 0.69 & $<2.2 \mathrm{E}-16$ & 224 \\
RDC & All & 0.229 & 0.013 & 1.92 & 0.05 & 0.68 & $<2.2 \mathrm{E}-16$ & 145 \\
CC & All & 0.155 & 0.01 & 2.03 & 0.03 & 0.65 & $<2.2 \mathrm{E}-16$ & 136 \\
NSM & All & 0.262 & 0.028 & 1.63 & 0.13 & 0.6 & $3.9 \mathrm{E}-13$ & 57 \\
BR & All & 0.237 & 0.01 & 1.68 & 0.05 & 0.85 & $<2.2 \mathrm{E}-16$ & 88 \\
MR & All & 0.193 & 0.009 & 2.05 & 0.03 & 0.8 & $<2.2 \mathrm{E}-16$ & 100 \\
\hline Global & High TL fish & 0.35 & 0.03 & 1.2 & 0.2 & 0.51 & $<2.2 \mathrm{E}-16$ & 185 \\
CAUP & High TL fish & 0.43 & 0.05 & 0.8 & 0.3 & 0.67 & $3.2 \mathrm{E}-11$ & 40 \\
RDC & High TL fish & 0.54 & 0.08 & 0.2 & 0.5 & 0.62 & $4.5 \mathrm{E}-08$ & 31 \\
CC & High TL fish & 0.28 & 0.07 & 1.3 & 0.5 & 0.61 & $8.0 \mathrm{E}-03$ & 7 \\
NSM & High TL fish & 0.39 & 0.13 & 0.9 & 0.8 & 0.43 & $8.0 \mathrm{E}-03$ & 13 \\
BR & High TL fish & 0.36 & 0.03 & 0.9 & 0.2 & 0.85 & $1.3 \mathrm{E}-14$ & 32 \\
MR & High TL fish & 0.33 & 0.04 & 1.2 & 0.2 & 0.83 & $1.5 \mathrm{E}-07$ & 16 \\
REF1 & High TL fish & 0.34 & 0.10 & 1.3 & 0.6 & 0.41 & $3.0 \mathrm{E}-03$ & 17 \\
CR & High TL fish & 0.08 & 0.08 & 2.9 & 0.5 & 0.07 & $3.3 \mathrm{E}-01$ & 13 \\
\hline
\end{tabular}




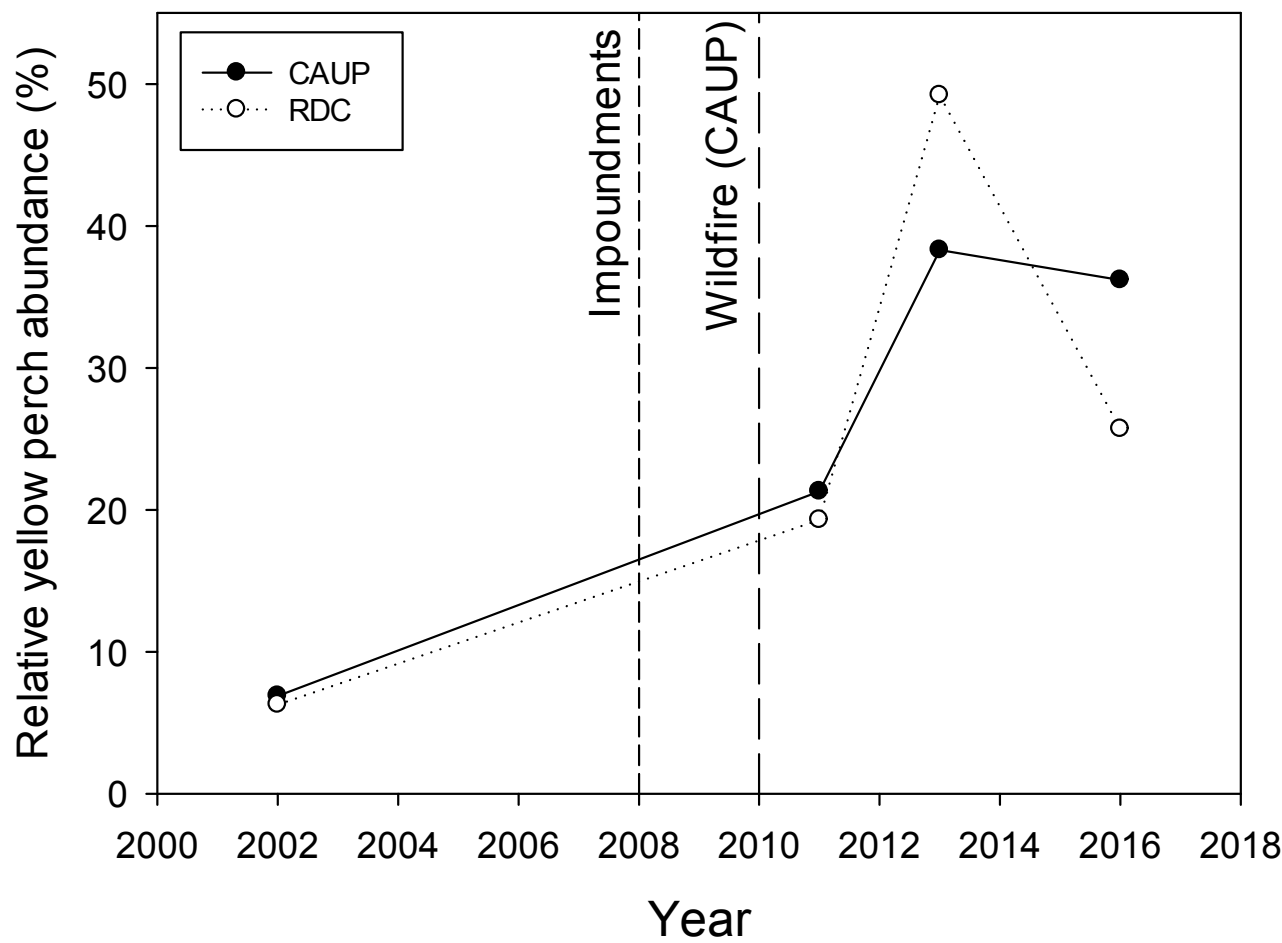

Figure S1: Relative abundance of yellow perch (Perca flavescens) in the run-ofriver pondages of Chute-Allard (CAUP) and Rapides-des-Coeurs (RDC) recorded during four community surveys between 2002 and 2016. The impoundment is indicated by the vertical short-dashed line, and the occurrence of a wildfire in proximity to CAUP is indicated by the vertical long-dashed line. 


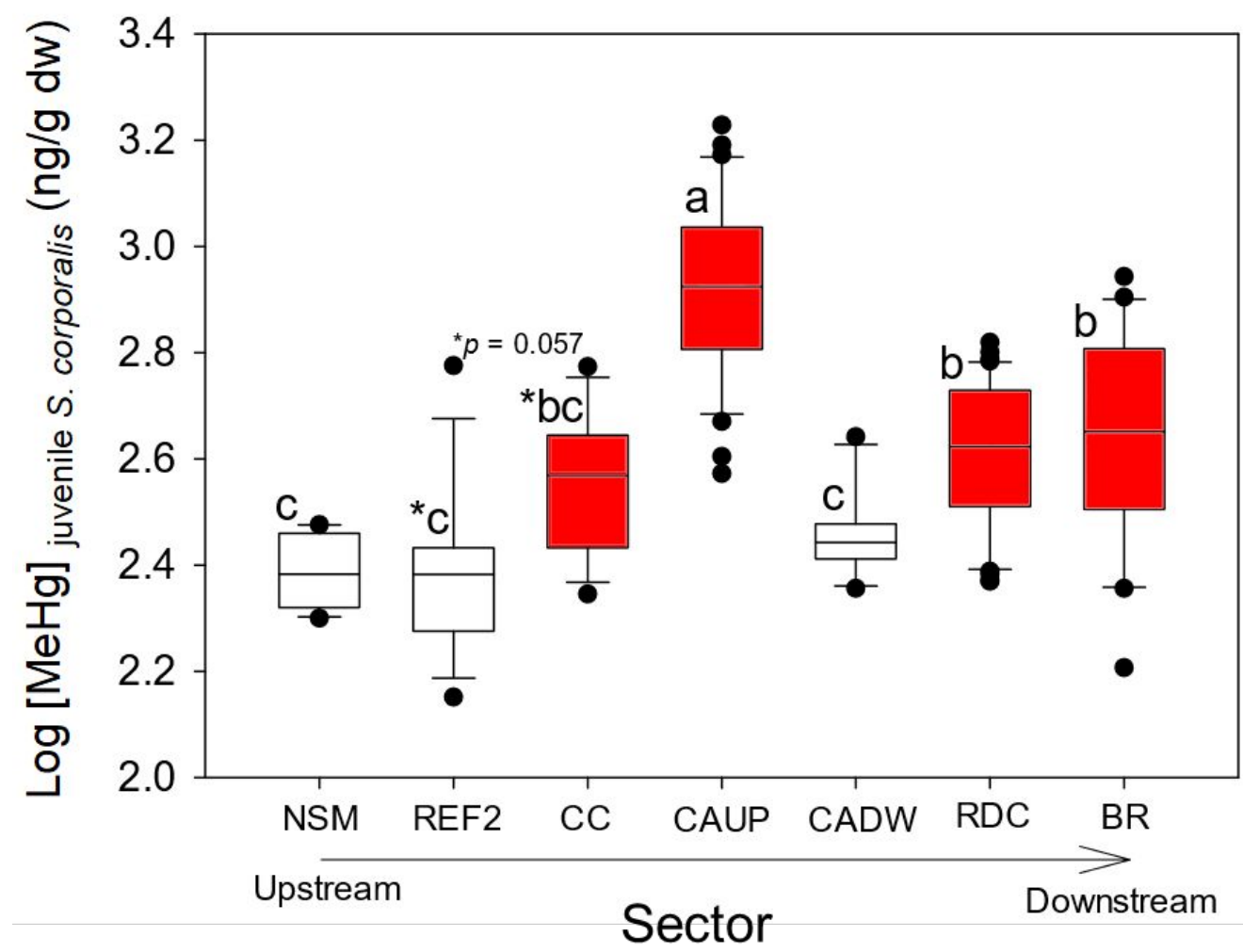

Figure S2. Box and whisker plots presenting log-transformed MeHg concentrations (log $[\mathrm{MeHg}], \mathrm{ng} / \mathrm{g} \mathrm{dw}$ ) in minnows (juvenile Semotilus corporalis) from various sectors. Flooded sectors are presented in red. 


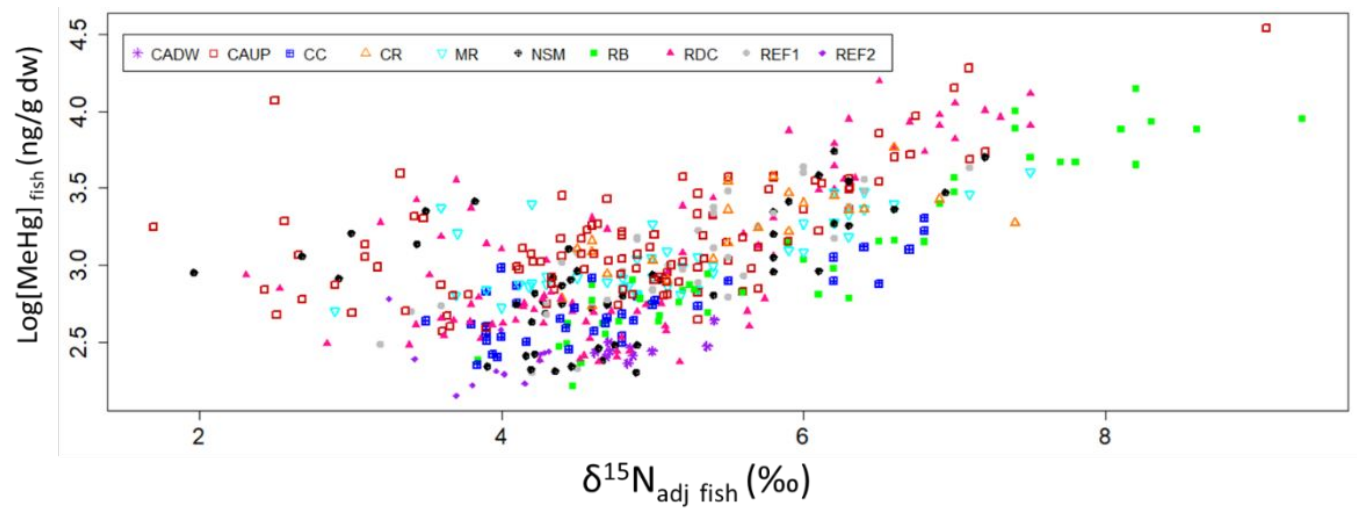

Figure S3. Log-transformed methylmercury concentrations in fish muscle (log [MeHg] (ng/g dw)) as a function of their baseline-adjusted nitrogen stable isotopic signature $\left(\delta^{15} \mathrm{~N}_{\text {adj }}\right.$; \%o) for all fish sampled from the Saint-Maurice River sectors from immediately downstream of the Gouin Reservoir (REF1) to the Blanc Reservoir (RB; see Figure 1).

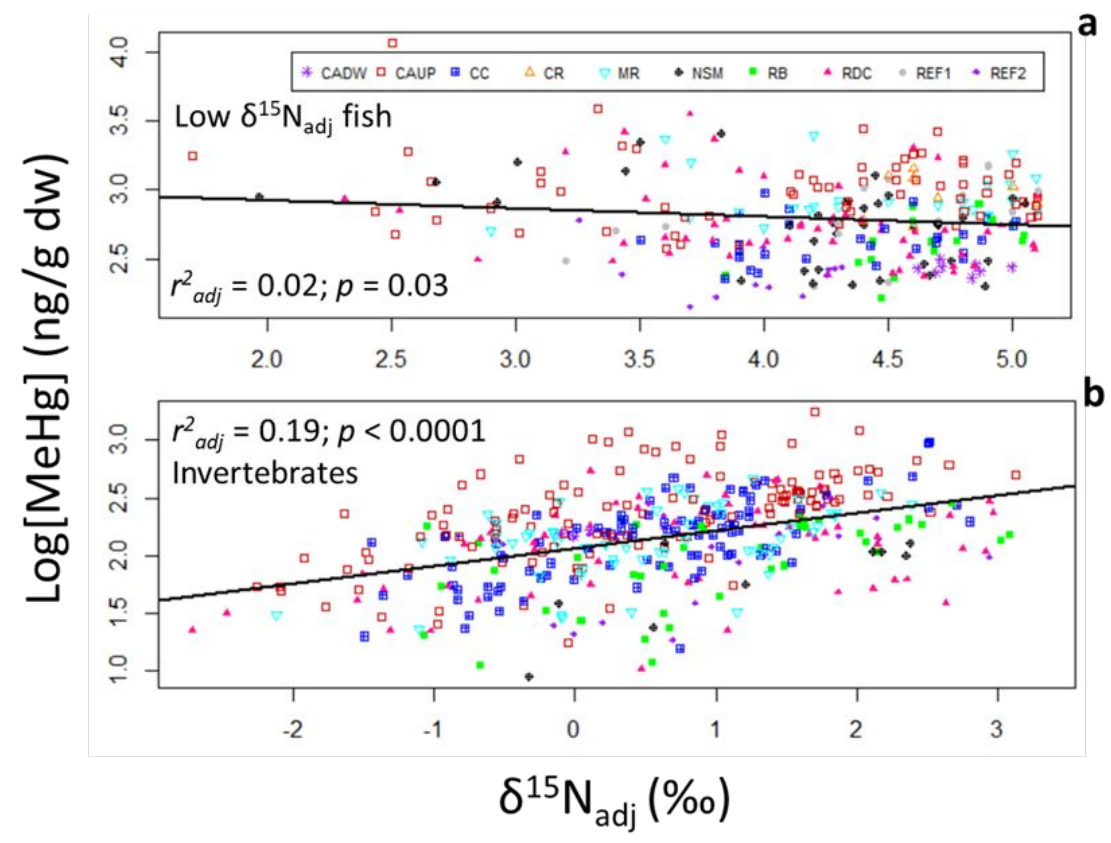

Figure S4. Regression between $\log [\mathrm{MeHg}](\mathrm{ng} / \mathrm{g} \mathrm{dw})$ and the adjusted nitrogen stable isotopic signature $\left(\delta^{15} \mathrm{~N}_{\mathrm{adj}} ; \%\right.$ o) for (a) fish at a trophic level lower than 3.5 and $(b)$ invertebrates collected from sectors along the Saint-Maurice River. Slopes are $-0.06 \pm 0.03$ and $0.15 \pm 0.02$ for panels $a$ and $b$, respectively. 


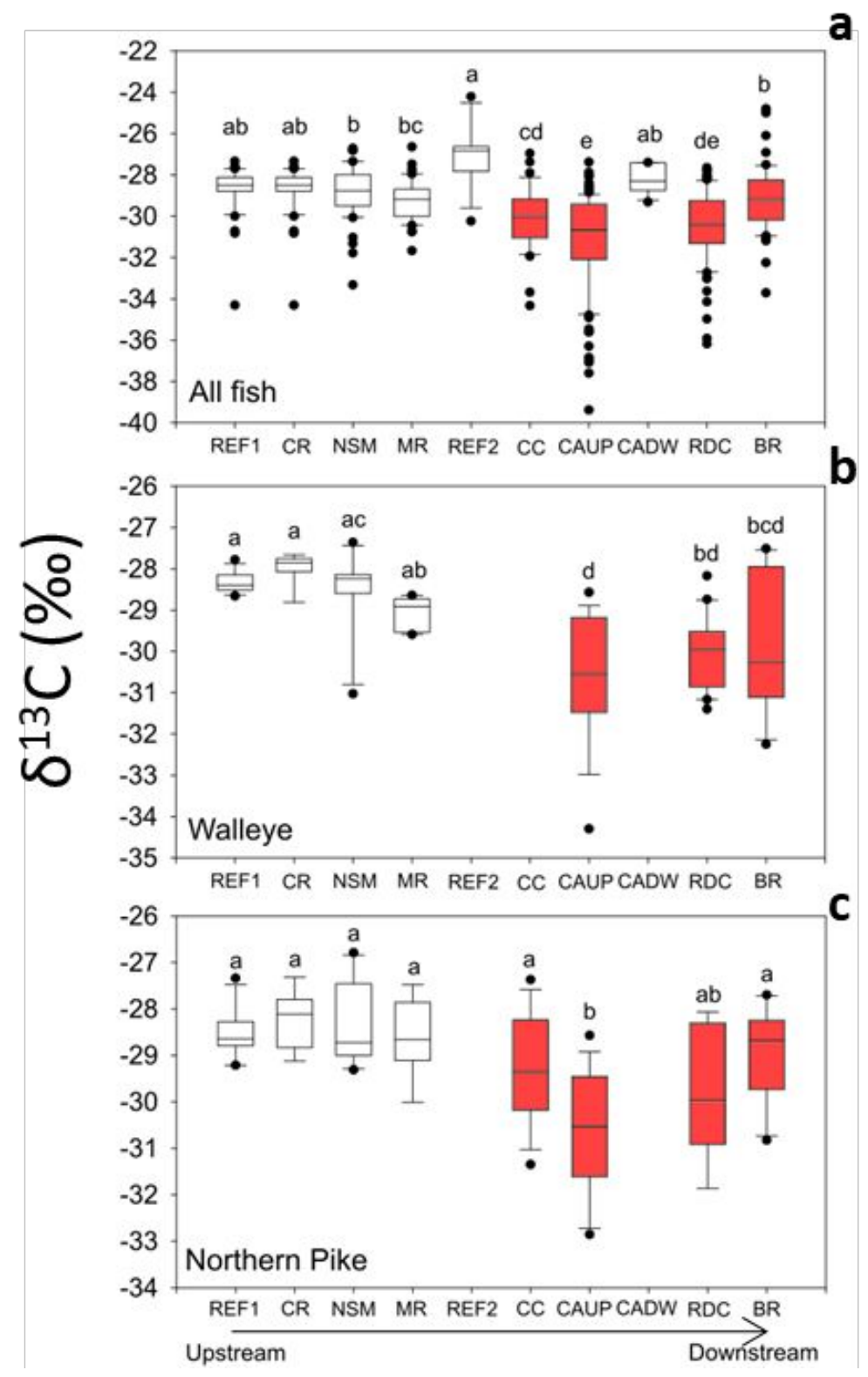

Figure S5: Fish carbon isotopic signatures $\left(\delta^{13} \mathrm{C} ; \%\right)$ from the sectors of the SaintMaurice River for (a) all sampled fish, (b) walleye (Sander vitreus), and (c) northern pike (Esox Lucius). We observed no significant differences for yellow perch (Perca flavescens; not presented). Red boxplots represent flooded sites. Different letters represent significant differences. 


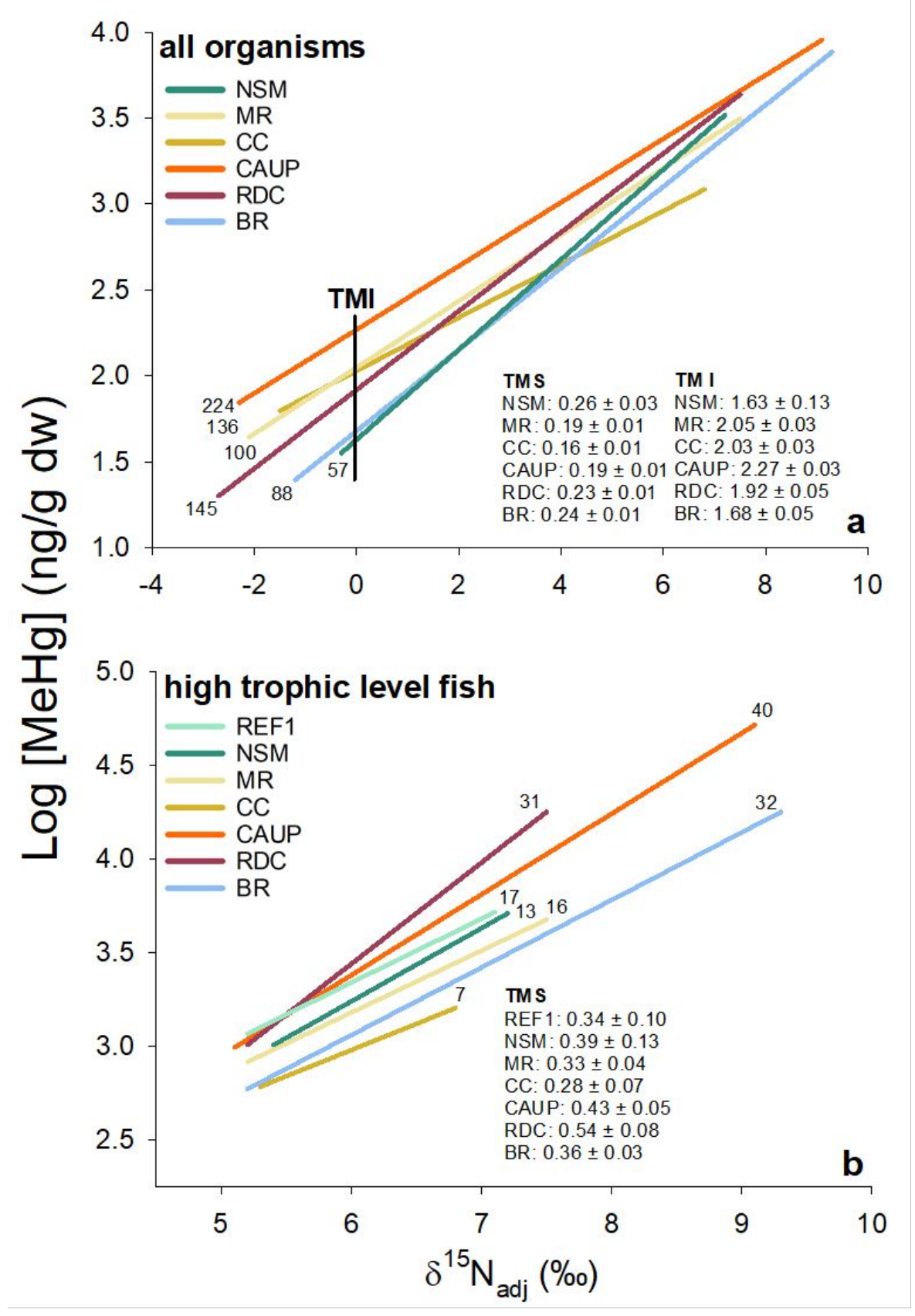

Figure S6. Log-transformed methylmercury concentrations (Log [MeHg], ng/g $\mathrm{dw}$ ) as a function of the sector-specific adjusted nitrogen stable isotopic signature $\left(\delta^{15} \mathrm{~N}_{\mathrm{adj}}, \%\right.$ o) for (a) all sampled organisms and (b) high trophic level fish collected from the Saint-Maurice River, Quebec. Degrees of freedom are presented with the TMS. Significant differences in trophic magnification slopes (TMS; log $\mathrm{ng} / \mathrm{g} . \% \circ$ ) and trophic magnification intercepts (TMI; log [MeHg], ng/g dw) are presented in Figure S6. The coefficients of determination $\left(r^{2}\right)$ and $p$-values are presented in Table S3 and Figure S6 (for all TMS, $r^{2}>0.43$ and $p<0.008$ ). 

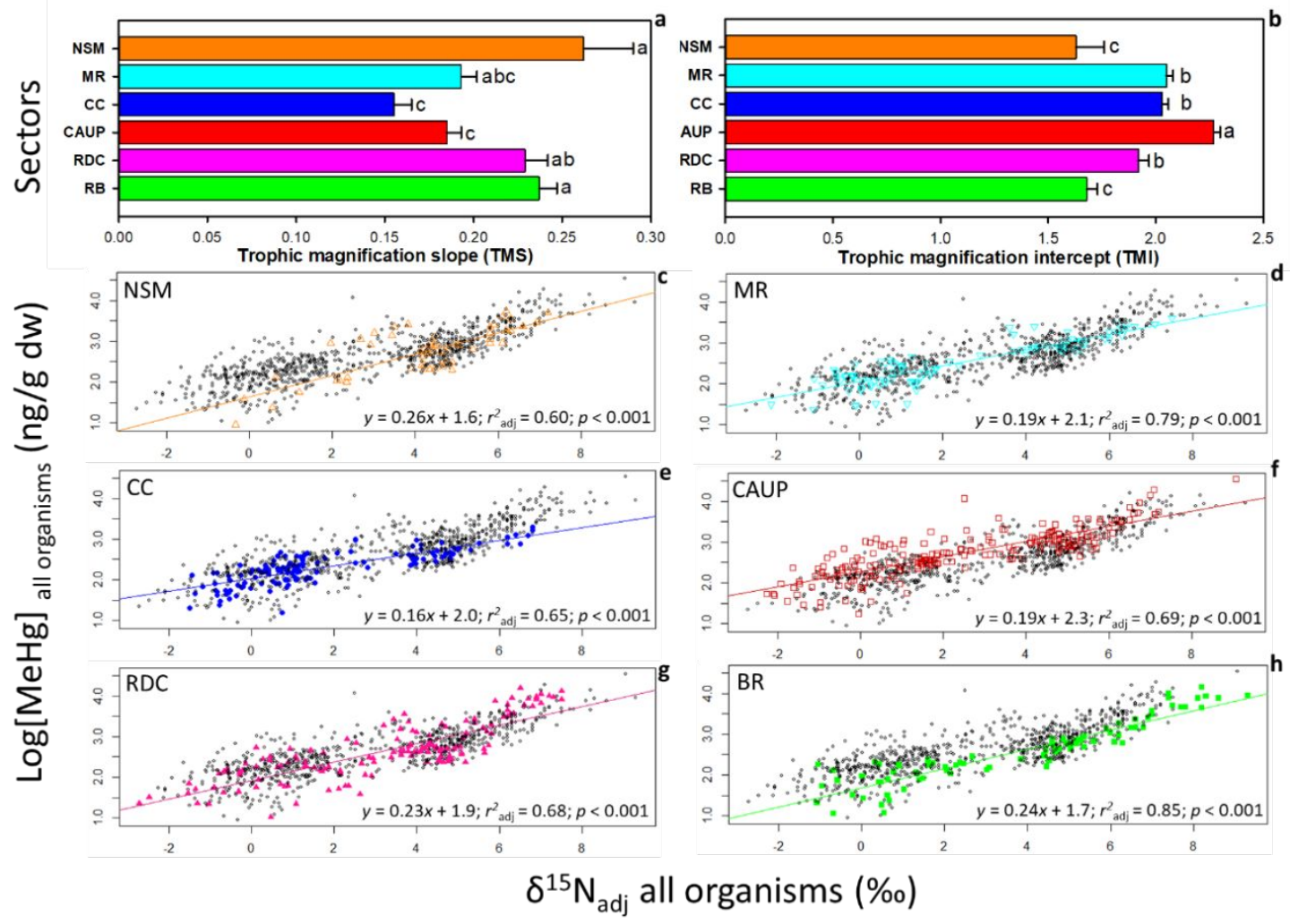

Figure S7: Bar graphs of (a) trophic magnification slopes (TMS; ng/(g dw·\%o)) and (b) trophic magnification intercepts (TMI; log[MeHg], ng/g dw). Regressions (c-h) between log-transformed methylmercury concentrations (log[MeHg], ng/g dw) and their baseline-adjusted nitrogen stable isotopic signature $\left(\delta^{15} \mathrm{~N}_{\mathrm{adj}}, \%\right.$ o $)$ for all organisms sampled along the Saint-Maurice River. Graphs are organized (c through h) from upstream to downstream from the junction of the Najoua and Saint-Maurice rivers (NSM) to the Blanc Reservoir (BR). Open black circles are samples from all sectors, and other symbols are for specific panel sectors. Different letters present significant differences between sectors. 


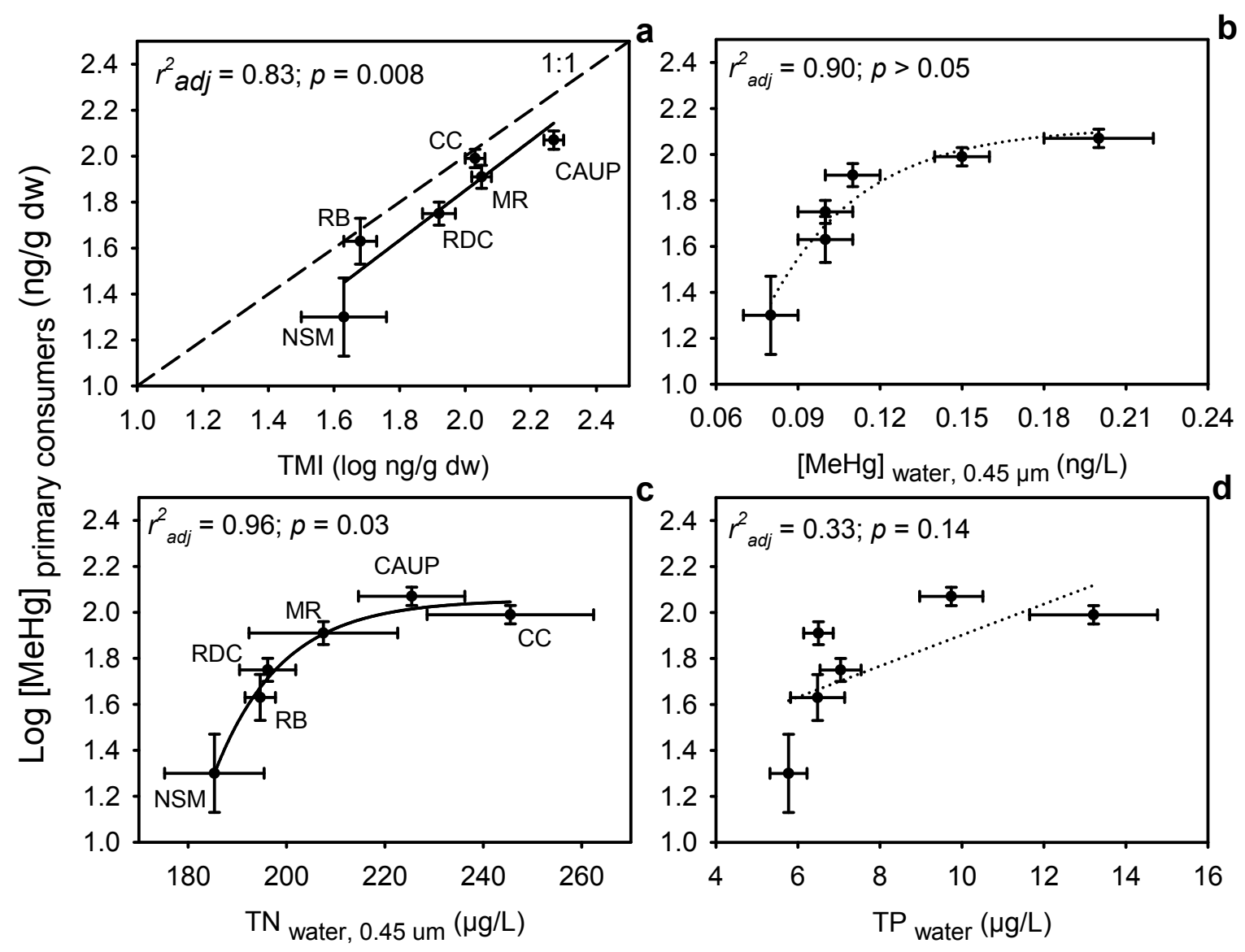

Figure S8: Log-transformed methylmercury concentrations of primary consumers ( $\log [\mathrm{MeHg}], \mathrm{ng} / \mathrm{g} \mathrm{dw}, \pm \mathrm{SE}$, details in Table S1) as a function of (a) trophic magnification intercepts ( $\log [\mathrm{MeHg}], \mathrm{ng} / \mathrm{g} \mathrm{dw}, \pm \mathrm{SE}$, details in Table S2); (b) dissolved [MeHg] ([MeHg] water, $0.45 \mu \mathrm{m}, \pm \mathrm{SE}, n=3-48$ ); (c) total dissolved nitrogen $\left(\mathrm{TN}_{\text {water, }} 0.45 \mu \mathrm{m}, \mu \mathrm{g} / \mathrm{L}, \pm \mathrm{SE}, n=3-48\right)$; and (d) aqueous total phosphorus (TP water; $\mu \mathrm{g} / \mathrm{L}, \pm \mathrm{SE}, n=3-48)$. Dashed regressions (b) and (d) are not significant $(p>0.05)$ 


\section{Literature Cited}

1. Houde, L., Teneurs en mercure dans les poissons du réservoir Gouin en 2002. Société de la faune et des parcs du Québec. Direction de l'aménagement de la faune de la Mauricie. Rapport technique. . Bibliothèque National du Québec 2004, 21.

2. AECOM, Aménagements hydroélectriques de la Chute-Allard et des Rapides-des-Coeurs. Teneurs en mercure dans la chair des poissons. Suivi environnemental 2013 en phase d'exploitation. In Hydro-Québec Production: 2014; p 59.

3. Sacotte, S.; Bilodeau, F., Aménagements hydroélectriques de la Chute-Allard et des Rapides-des-Coeurs. Teneurs en mercure dans la chair des poissons. Suivi environnemental 2016 en phase d'exploitation. In Hydro-Québec Production: 2017; p 87.

4. Khadra, M.; Caron, A.; Planas, D.; Ponton, D. E.; Rosabal, M.; Amyot, M., The fish or the egg: Maternal transfer and subcellular partitioning of mercury and selenium in Yellow Perch (Perca flavescens). Sci. Tot. Environ. 2019, 675, 604-614.

5. EPA, U. Method 1631, Revision E: Mercury in Water by Oxidation, Purge and Trap, and Cold Vapor Atomic Fluorescence Spectrometry; United States Environmental Protection Agency: 2002; $\mathrm{p} 38$.

6. EPA, U. Method 1630 - Methyl Mercury in Water by Distillation, Aqueous Ethylation, Purge and Trap, and Cold Vapor Atomic Fluorescence Spectrometry; United States Environmental Protection Agency: 1998; $\mathrm{p} 46$.

7. Campeau, A.; del Giorgio, P. A., Patterns in $\mathrm{CH} 4$ and $\mathrm{CO} 2$ concentrations across boreal rivers: Major drivers and implications for fluvial greenhouse emissions under climate change scenarios. Global Change Biology 2014, 20, (4), 1075-1088.

8. EPA, U., Method 365.3: Phosphorous, All Forms (Colorimetric, Ascorbic Acid, Two Reagent). United States Environmental Protection Agency 1978.

9. Lachat, Determination of nitrate/nitrite in drinking, surface and wastewaters by flow injection analysis: QuickChem Method 10-107-04-1-C. Lachat Instrument 2008.

10. AECOM, Aménagements hydroélectriques de la Chute-Allard et des Rapides-des-Coeurs. Suivis des communautés de poissons dans les biefs de la Chute-Allard et des Rapides des Coeurs. Suivi environnemental 2016 en phase d'exploitation. In Hydro-Québec Production: Direction Production des Cascades, 2017; p 115. 